\title{
Funding community organising: diversifying sources, democratising civil society
}

Throughout the history of community organising in the United 16 States, funding has been a serious and, until recently, neglected issue 17 (Fisher, 1994). This chapter recognises the variety, complexity and 18 contested politics of community organising, a practice that ranges 19 from consensus-based community building to more conflict-oriented 20 grassroots organising confronting oppression. Our main interest is the 21 need for movement-like organising for economic and social justice 22 at the local level and beyond. Since 2008, funding for organising in 23 the US has declined. A 2009 National Organizers Alliance survey 24 of 203 community organisations reported that $65 \%$ of respondents 25 had undergone dramatic funding cuts since the recession, 40\% had 26 depleted their financial reserves, and 33\% survived on a month-to- 27 month basis (Waheed et al, 2010). According to an Urban Institute 28 study, community organising organisations were hit the hardest (Boris 29 et al, 2010). While there has been increasing interest in community 30 organising since the election of Obama in 2008, 'one of the most 31 important questions facing organisers [remains] can we translate this 32 growing public awareness into serious funding that will propel growth 33 and strengthen the field?' (Dorfman and Fine, 2009: 2). 34

This chapter will make the case that an over-reliance on progressive $\quad 35$ philanthropic sources has resulted in the underfunding of community 36 organising. It has also contributed to the depoliticisation of 'civil 37 society' (we will scrutinise the use of this term more closely later) 38 and has obscured the potential role the state can play in achieving $\quad 39$ egalitarian social change. We argue that it is time to diversify funding $\quad 40$ sources for community organising and to re-evaluate debates in the 41 field about the limits and difficulties associated with state funding. 42 
We foreground a case study from outside the US - the Community Organising Programme (COP) (2011-2015) in England - to illustrate how state funding for community organising can lead to progressive outcomes, even when initiated by a Conservative government that is firmly committed to neoliberal policies. Community organisers in the US have, we believe, much to learn from this programme. We argue that a failure to advocate for greater state support for US community organising unintentionally reinforces the delegitimisation of the state which has occurred under neoliberalism and limits the scope and power of grassroots organising.

The chapter begins by outlining the value of community organising and the variety of funding models currently in operation in the US before turning to a review of critical debates on funding for community organising in which we think the importance of public sector funding is generally underplayed. It then makes the case that highlighting the importance of public sector funding for community organising highlights the existing interconnections between civil society, state and market. This offers a way of challenging depoliticised interpretations of civil society and, ultimately, we argue could serve counterhegemonic purposes. Finally, the COP case is presented in support of these claims. The aim is to contribute to debates on resourcing community organising and democratising state and civil society under neoliberalism (Edwards, 2010; Trudeau, 2012; Fisher and Shragge, 2017).

\section{The importance of community organising}

The value of community organising has been widely recognised (Boyte, 1980; Warren, 2001; Staples, 2004). Walker and McCarthy (2012) [[see query in References]] suggest that grassroots organising contributes to substantial changes in communities, improving employment opportunities, workplace conditions, neighbourhood safety and the quality of public services. These initiatives also empower people and amplify the voices of poor and moderate-income citizens in the public sphere. To pick just one example, Delgado (2009: 268) highlights the success of ACORN, once the largest community organising organisation in the United States, in 'successfully accruing power and benefits for its low-income base.' ACORN blended a conflict-oriented labour union strategies and tactics with a social movement culture and sought to organise at the local as well as national and even international level. ACORN's contributions included getting its members, primarily people of colour, to act in their own interest, on issues such as a living 
wage, better housing and services and predatory financial lending practices. It achieved this by creating strong community organisations, building a multiracial constituency, developing both local and national capacity, experimenting with alternative institutions, engaging in electoral politics, internationalising membership beyond US borders, and using conflictual tactics such as direct action protests.

Clearly community organising is not without its limits or critics. Romanticisation of community and community initiatives is widespread (Joseph, 2002). Major contemporary challenges include sustaining organisations over time, developing and advancing progressive goals in hostile conditions, building beyond local contexts in order to increase power and impact, fending off attacks from the Right if an organisation successfully accrues scale and power and having enough capacity to hire community organisers to provide leadership, training and continuity. As Dodge et al (2013: 2) puts it, 'We are in a moment when it is critical to make investments in learning and experimentation to better understand what support can increase long-term sustainability for social justice organizations.' Before exploring critical issues of resourcing and sustainability, an overview of the predominant forms of funding used in contemporary community organising in the US is in order.

1

2

3

4

5

6

7

8

9

10

11

12

13

14

15

16

17

18

19

20

21

22

23

24

25

26

27

28

29

30

31

32

33

34

35

36

37

38

39

40

41

42 
in 2006 concludes that the social change sector received $62 \%$ of its funding from foundation grants. Government sources represented only $5 \%$ of total funding for these organisations. Current funding is driven by institutionalised practices, network connections and accepted norms and what is viewed as convenient sources (Beckett et al, 2006: 5). Of course this over-reliance on the philanthropic sector has spawned a literature highly critical of philanthropic funding (INCITE! Women of Color Against Violence, 2007; Ashton and DeFilippis, 2014) and has helped to ignite a debate regarding alternative funding sources for progressive social change.

\section{A review of the debates on funding community organising}

Despite the funding crisis within community organising and the corresponding need for diversifying funding sources, the debate over funding remains curiously 'stuck' and public sector funding of community organising is rarely mentioned within the US literature on this topic. For example, Beyond foundation funding: Revenue-generating strategies for sustainable social change (Dodge et al, 2013), a study which is wary of the anti-democratic dimensions of 'philanthrocapitalist' foundation funding, concludes by encouraging more dialogue between foundations, social change organisations and technical assistance providers. ${ }^{2}$ This conclusion is especially intriguing given their critique of foundations as beneficiaries of the state as well as their understanding of the prominent role the public sector plays in funding human service organisations. Similarly, a report of the National Committee for Responsive Philanthropy and the Center for Community Change proposes that this is a good time to fund community organising. They advise developing 'good relations and expanding networks with a wide variety of donors and funders,' but focus almost exclusively on philanthropic sources (Dorfman and Fine, 2009: 2).

INCITE!'s The revolution will not be funded (2007) sharply criticises social change organisations' reliance on philanthropic foundations. For the Women of Color Against Violence collective, foundations are part of the problem, supporters of the status quo. But INCITE!'s suggestions regarding alternative models - membership dues and partnerships with other community organisations - also focus heavily on sources within the civil society sector. Most recently, a Center for Popular Democracy report, Seeding justice (2015), identifies lessons of revenue generation from the field of mass base-building organisations. While the study recognises the need to diversify funding streams and become less dependent on grants from foundations for their financial 
health, it excludes public funding as a possible source. This relates in part from an analysis, questioned by others, that an overdependence on federal funding caused ACORN's downfall in 2009 (personal 3 communications, former ACORN employee, 2016).

Another stream in the literature explicitly warns against public 5 sector funding for social change. For example, Piven and Cloward 6 (1978) illustrate how state funding and government involvement $\quad 7$ lead to the control of labour and movement incorporation, blunting 8 militancy, inhibiting membership growth and weakening membership $\quad 9$ ties. They contend it shifts the focus from grassroots organising and 10 brings movements into the maze of legislative and bureaucratic politics. 11 More recently, problems of government contracting are examined 12 in Fabricant and Fisher's (2002) study of contemporary settlement 13 houses in New York City where organisations were trying to survive 14 draconian budget cuts, excessive project goals and bureaucratic burdens. 15 These grassroots organisations were under siege due to the highly 16 partisan, unstable and demanding system of government contracting 17 and cutbacks brought about by the right-wing 1994 'Contract with 18 America'.

While critics underscore the problems associated with both current government programming and dominant forms of charitable giving, including movement philanthropy, some do acknowledge the potential of public funding of democratic initiatives. For example, Wolch (1990: 224) argues that the involvement of the state 'could lead to greater state control over everyday life and/or to an extension of participation and democracy.' Fabricant and Fisher (2002: 290) concur and conclude their study with a call to challenge the privatisation of contemporary government contracting, rather than the public sector per se. Organisations must struggle to balance the dynamic of maintaining their core mission and avoiding incorporation and manipulation. Michael Edwards captures these complexities well. He argues that money is both the 'beauty' and 'beast' in community organising, no matter the funding source. "In market-based societies "money talks", but it rarely speaks the language of democracy and social justice. Recognizing and acting on this fact is vital rather than pretending that money is somehow neutral or separated from the broader processes in which it is accumulated, expended, and exchanged' (2013: 5).

Clearly neoliberal hegemony makes achieving public sector funding more difficult than before. For some, a key task is to render the system of outsourced public governance more effective (Salamon, 2002). In our view, what matters most in the struggle against neoliberal hegemony is the democratisation of the public sector and civil society.

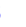
4

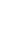
7

8

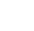

10

1

2

3

4

5

6

17


For example, the welfare state, a primary target of neoliberalism, is not simply a tool of capitalist hegemony; it reflects concessions won by popular struggles. Publicly funded community organising can itself be a challenge to the shrinking state under neoliberalism. It has the potential to contribute to counterhegemonic movements with the potential capacity to win crucial concessions. Even in the historically weak and decentralised state form that has predominated in the US, gains secured by publicly funded organising during the 1930s and 1960s are clear examples of this sort of 'democratic realignment', a point which we will return to below.

\section{Relations between state, civil society and market}

The argument for diversifying funding for community organising and to seek public sector support for such activity rests on two key claims: we must challenge the idea that civil society can be regarded as independent of either state or market; and we must recognise the role that public funding has historically played in funding social change in the US.

First, it is worth recalling that there are long-standing interconnections between civil society, state and market through the existence of funding partnerships, tax breaks for philanthropy, policy networks and other such phenomena. The erroneous idea that civil society constitutes a sphere separate from the state and the market has been reinforced by developments over the last 40 years. Ehrenberg (2011: 23) argues that the revival of the notion of civil society over the past generation has its origins in the antagonism towards the state of Eastern European dissidents who called for 'a revolt of civil society against the state'. Thus, civil society has become associated with a celebration of the local as the source of democracy (Bellah et al, 1985) while the state became associated with top-down control. But this coincided with the emergence of a neoliberalism in the mid-1970s that also distrusted the 'big state' and has led to the hollowing out of social welfare and the outsourcing of public services to business (DeFilippis et al, 2010; Smith, 2011).

The reality is far more complex than this notion of civil society allows for - the state, market and civil society are highly interrelated and the 'public' and 'private' are not easily disentangled. We believe it is useful to begin with this premise in analysing possible sources of funding for organising. For example, the philanthropic sector uses public sector subsidies in the form of tax breaks and exemptions. While private foundations are said to control their funds for private 
ends, in reality they 'intervene in public life with no accountability 1 to the public required' (Barkan, 2013). The Gates Foundation's work 2 around charter schools and public school reform is highly political 3 and controversial, as is the conservative lobby group ALEC (American 4 Legislative Exchange Council). Such 'civil society' organisations use 5 'wealth derived power in the public sphere with minimal democratic 6 controls and civic obligations' (Barkan, 2013). Greater public funding $\quad 7$ for community organising could arguably serve as something of a 8 counterbalance to the unaccountable political influence of policy- 9 active philanthropies.

Second, despite contemporary historical amnesia about the role of 11 public funding, as we noted briefly before, the US government has a 12 long history of funding social change. There is an authentic and deep, 13 if intermittent, tradition of state action to address inequalities on a 14 significant scale (DeFilippis et al, 2010). Although since 1980 there 15 has been a major thrust, largely successful at the national level, to 16 undermine the federal government, there is a well-established practice 17 of state funding for social change in the US. There are historical 18 examples that should remind both practitioners and academics not 19 to exclude the state as a potential partner in supporting community 20 organising and grassroots social change. In the 1960s, for example, 21 President Johnson's 'Great Society' and, more specifically, the 22 Community Action Program offered a model of federally funded 23 community action as an instrument of social reform grounded in 24 an anti-racist, anti-poverty, participatory view of democratic politics 25 (Korstad and Leloudis, 2010). Since then there have been a series of 26 government programmes that funded organising, including VISTA 27 (Volunteers in Service to America), which trained volunteers as 28 organisers in the late 1970s, and support for organisations challenging $\quad 29$ bank redlining and predatory lending during the Clinton era (Dreier, 30 1996).

The interrelationships between state, market and civil society in the here and now and the longer historical record of state initiatives 32 are especially important to bear in mind in a neoliberal era. While acceptance of state funding can, as critics have highlighted, lead to the spread and 'normalisation' of neoliberal values and practices (Larner and Craig, 2005), the narrow focus on civil society as a 'pure' and separate sphere, and the belief that it is more legitimate to secure funding from within civil society rather than from outside it, arguably 33 
help challenge the delegitimisation of the state that has occurred under neoliberalism.

\section{The Community Organisers Programme}

In 2011, the British Conservative government under David Cameron initiated the COP in England to hire and train 500 'senior organisers' and educate 4,500 volunteers in the basics of community organising. With government funding of approximately $£ 20$ million (Fisher and Dimberg, 2015), its explicit focus on the hiring and training of community organisers on such a grand scale is extraordinary. What is also singular about COP is that it emerged from Cameron's socalled 'Big Society' initiative that fused neoliberal and communitarian goals by arguing for a strong role for the state in strengthening communities and expanding grassroots participation (Balazard and Fisher, 2016). Big Society organisers would, it was argued, 'facilitate local action and give support to groups looking to come together to tackle identified problems' (Cabinet Office, 2013: 1). It was, however, intended primarily to undercut the British welfare state (Fisher and Shragge, 2017). In fact, at the same time of Cameron's unveiling of 'Big Society' policies, Chancellor of the Exchequer George Osborne concurrently announced a five-year austerity plan that included the largest budget cuts since the Second World War and the elimination of almost half a million public sector jobs (O'Hara, 2014). In a period of neoliberal policies and austerity the Big Society plan was not fully implemented. But COP remained and continued to move forward through the end of Cameron's first term in 2015, partly because it was already contracted out to two organisations, Locality and RE:generate, and partly because it attracted so much interest, especially among existing community development professionals and among people wanting paid work as community organisers (Fisher and Dimberg, 2015). That interest and support continues; in March 2017, the COP legacy organisation, the Company of Community Organisers (COLtd), received a $\mathcal{E} 4.2$ million contract from the post-Cameron Conservative government's Office of Civil Society for further training of community organisers (Community Organisers Ltd, 2017).

While the value and the impact of the COP remain contested it nevertheless provides an illuminating example through which to explore the limits, but also the potential, of state-funded community organising in a neoliberal era. Drawing on secondary research and on interviews undertaken during the summer of 2014 with COP staff, organisers and external organising professionals, we can state 
that COP clearly promoted a neoliberal interpretation of community organising that lent support to the retreat from public service delivery. But it also provided, amid draconian budgetary cuts and austerity policies, an alternative opportunity for the development of movementlike community organising inspired by the ideas of US community organiser Saul Alinsky (1972). Alinskyite approaches typically involve the recruitment of trained organisers who build power within poor communities by mobilising its members and forging alliances with organisations with common interests. Tactics range from negotiation to more confrontational modes of protest (Taylor, 2011).

There was some ambivalence in the government's approach to the programme. On the one hand, a preference for a more consensual community organising model can be discerned from the fact that Locality (2010) won the tender to operationalise COP over Citizens UK, an organisation loosely affiliated with the IAF (Industrial Areas Foundation), the direct heir to Alinsky organising in the US. The Locality tender emphasised personal responsibility, entrepreneurialism and assets-based approaches, which are characteristic of more neoliberalised models of community organising. On the other hand, while most observers think that Citizens UK didn't get the contract because its approach was too confrontational (Third Sector, 2011), other experts suggest the Cameron administration was selectively open to collective action on the part of citizens and, where it suited Cameron's political interests, to protest tactics targeted at public authorities. According to one source, the Cameron administration had no problem with citizens marching on local town halls to reform public services, especially in Labour Party strongholds (M. Taylor, personal communication, 12 October 2014). Indeed, at first Cameron had seemed willing to give the bid to Citizens UK. He was quite taken with an impressive Citizens UK meeting where he told the large audience, 'You are the Big Society.' Cameron advisers were sent to the US to meet with the American equivalent of Citizens UK and with President Obama advisers on how Obama used community organising to get elected in 2008 .

Evidence of varying discourses, different types of political commitment and diverse modes of engagement are also evident within the programme itself. The capacity for COP to achieve far-reaching social change was stymied by the training model used by the programme which followed traditional forms of government-funded community development in the UK rather than using more radical models (Craig et al, 2011; Scott, 2011). For much of the four years, RE:generate (Action to Regenerate Community Trust), the organisation which

1 2 3 4 5 6 7 8 9 10 11 12 13 14 15 16 17 18 19 20 21 22 23 24 25 26 27 28 29 30 31 32 33 34 35 36 37 38 39 40 41 42 
provided the training on behalf of Locality, delivered a depoliticised community-building model. Its 'Root Solutions - Listening Matters' (Kearney and Olsen, 2009) educational programme emphasised the basics of listening to local people, letting them decide on key issues and projects. Training sessions held by RE:generate focused more on resolving, rather than creating conflict, and on building relationships with all stakeholders rather than challenging people in positions of power. They were much stronger on process and relationship building than organisation building or social justice outcomes.

Besides these training modules, for a year organisers had to 'listen' to 500 people, recruit and train nine volunteers and help three projects come about, even if they stayed at the level of an idea. The projects mainly depended on a few training sessions offered to residents that focused on the creation of social network bonds, neglecting the importance of creating organised groups and actions. Despite the progressive inclinations of Locality staff and Board members, the choice of this depoliticised model had a huge impact in determining the types of issues selected and results accomplished. For example, much of the community work was about helping improve service delivery and outreach in 'host' social welfare organisations or activities such as creating community gardens, litter picks, an annual music festival for young people, and neighbourhood watches.

However, there were also instances where Alinsky-style community organising did occur. Though a large number of organisers have indeed focused on community-building methods (listening, building relationships, recreating a sense of community and using existing assets), a minority of organisers succeeded in using direct action to help groups to organise and voice demands to improve their living conditions. Among these latter initiatives, one can find the Sheffield group of residents who managed to pressure local authorities to save a bus line and the development of an ACORN branch in Bristol, which took actions for economic and social justice, especially around housing issues (Rathke, 2015).

In fact, interviews conducted in 2014 revealed a great deal of autonomy at the grassroots level. The lack of a political vision for this experimental programme and the loose management in each organisation hosting trainees gave the organisers a significant degree of independence. This 'hands-off' policy was a surprise to almost everyone, including Locality staff, but especially those hired as organisers. Young people who had applied for the job because of their commitment to changing society used their relative independence to implement action-oriented community organising: "Some people 
got really dispirited by the lack of structure, the lack of training. I 1 just thought great, I can do what I want. This is a great opportunity. 2 Because I come from a politicised background, I do want to change 3 things. This is the first step towards doing that" (organiser A). 4

Furthermore, as organisers were part of the same cohort, being and 5 reading together enabled them to voice critiques of the programme 6 and to build alternative visions of community organising: $\quad 7$

'The people on our team were all pretty bright individuals 9 and so we would have our team meetings every week and 10 there were great moments for us to kind of develop our own $\quad 11$ ideas around what community organising should be and 12 what we didn't like about the programme, ... eventually that $\quad 13$ what was led us in to building ACORN now. (Organiser B) 14

Another positive impact of the COP was noted by this participant: 16 "The great thing about the programme is the idea that, along with 17 your salary in year 1, you were also given matched funding in year 18 two so that you could go out and set up your own organisation" 19 (organiser B). 20

A critical lesson of hiring and training people to do this work is 21 that they often come with activist politics and, given the chance, 22 pursued more radical forms of community organising and civic 23 engagement. Such outcomes are not unprecedented. As a result of 24 state incorporation of local community organisations, Trudeau (2012: 25 442) finds that community organisations in the US are increasingly 26 able to 'inflect agendas with other priorities or subtly resist them'. $\quad 27$

It is easy to dismiss the Big Society and its associated funding 28 initiatives as neoliberal policies disguised as reforms to strengthen civic $\quad 29$ life and local participation. The COP can, with some justification, 30 be seen 'as a mechanism by which business and state co-opt and 31 compromise integrity and independence of civil society activities 32 previously based around participation, active citizenship and political 33 change' (Nicholls, 2011: 80) [[see comment in References]]. 34 But such analyses miss the particular distinctiveness and potential 35 importance of COP. It was the largest and best-funded social change 36 initiative in more than a generation explicitly focused on hiring and 37 training community organisers. Even with the programme's obvious 38 limits in terms of training and outcomes, it did, in places, help to 39 seed a more transformative model of community organising and, not 40 to be underestimated, it further legitimised community organising 41 as an approach to community development in England. Despite the 42 
dilemmas and contradictions this form of funding has entailed its effect on community organising cannot be fully predicted.

\section{Conclusion}

As Taylor and Wilson (2016) note, all organising, especially among disenfranchised groups, is difficult, complex and challenging work and obviously this valuable activity requires funding. We have argued that there is a strong case that community organising in the US should demand, and seek the legitimation of, more public funding especially from the state. Among community organisers and researchers in community development there is a well-established critique of relying on state funding. However, we think circumstances have changed and we need to reconsider this position. The long-term effects of neoliberal thinking have had an enormous impact and part of the response to this should be, we believe, a struggle to democratise the state and to challenge depoliticised interpretations of civil society.

Moreover, as discussed earlier, we need to bear in mind the realities of funding community organising through sources other than the state. Such sources carry risks similar to those associated with state funding, that is to say, funders setting the agenda, insecurity of funding over the medium term and so forth. At least with the state there is a conception, however notional, of the public good and historically we know this can be built on in significant ways. We also know that even in unpropitious circumstances, such as under a strongly neoliberal government of the British Conservative Party, securing funding for community organising can have important and interesting unintended consequences.

Our aim here is to provoke debate and to engage in dialogue on how we can best rethink funding community development. There is no simple answer on how to approach this. What we have done is provide arguments and models for considering how to broaden funding efforts. The ultimate aim is to support community organising in the belief that it has a vital role in addressing critical societal needs such as the widespread contemporary challenges to democracy. The public sector - at the local, state and/or national levels - should be reconsidered as a potential ally and target, depending on the context, for the public support of grassroots initiatives in social change and democratic practices. In the US, with the Trump administration (in office as at the time of writing), public funding of progressive community organising is most likely to come from state and city levels, certainly not from the federal government. Nearly all funding comes 
with 'conditions' and it requires careful thought and consideration 1 to maintain core organisational practices and values and to avoid 2 manipulation in securing and sustaining funding. But neither the 3 contemporary turn to the Right, nor evidence of incorporation and 4 'domestication' of community organising in the past through public 5 funding, should lead us throw up our hands and cede the vital territory 6 of the state to other forces. Accordingly, we propose that diversifying 7 and expanding resources for community organising, while seeking to 8 democratise the state and civil society, are crucial short- and long-term $\quad 9$ $\begin{array}{ll}\text { strategies for transformative change. } & 10\end{array}$

\section{Notes}

1. One significant example of this was ACORN's campaign against H\&R Block, a US multinational tax preparation company, which won funds for ACORN and reduced predatory rates for neighbourhood people (see Fisher et al, 2007).

2. Technical assistance providers consult not-for-profit organisations on development and funding matters.

\section{References}

Alinsky, S. (1972) Rules for radicals, New York: Vintage Books. 20 Ashton, P. and DeFilippis, J. (2014) 'Now where I'll find comfort, 21 God knows, 'cause you left me just where I needed you most: Non- 22 profits, business cycles and the remaking of the American welfare 23 state' (unpublished manuscript). 24

Balazard, H. and Fisher, R. (2016) 'Community organizing: Remedy 25 to neoliberal policies or slow revolution?', Mouvements, 85: 105-113. 26 Barkan, J. (2013) 'Plutocrats at work: How big philanthropy 27 undermines democracy', Dissent, Fall, www.dissentmagazine.org/ 28 article/plutocrats-at-work-how-big-philanthropy-undermines- $\quad 29$ democracy. $\quad 30$

Beckett, J., O'Donnell, S. and Rudd, J. (2006) 'Fundraising practices in 31 community organizing', Shelterforce Online, 145, https://web.archive. 32 org/web/20060512153912/http://www.nhi.org/online/issues/145/ 33 fundraising.html. 34

Bellah, R.N., Madsen, R., Sullivan, W.M., Swidler, A. and Tipton, 35 S.M. (1985) Habits of the heart: Individualism and commitment in American 36 life, Berkeley, CA: University of California Press. 37

Boris, E., de Leon, E., Roeger, K. and Nikolova. M. (2010) Human 38 service nonprofits and government collaboration: Findings from the 201039 national survey of nonprofit government contracting and grants, Washington, 40 DC: Urban Institute. $\quad 41$ 
Boyte, H.C. (1980) The backyard revolution: Understanding the new citizen movement, Philadelphia, PA: Temple University Press.

Cabinet Office (2013) Big Society: Frequently asked questions, www. gov.uk/government/uploads/system/uploads/attachment_data/ file/85850/Big_Society_FAQs.pdf.

Center for Popular Democracy (2015) Seeding justice: Revenue-generating membership and fundraising canvasses for community organizing: Lessons from the field, 21 October, Washington, DC: Center for Popular Democracy, https://populardemocracy.org/news/publications/ seeding-justice-revenue-generating-membership-and-fundraisingcanvasses-community.

Community Organisers Ltd (2017) Massive expansion of community organisers programme, 2 March, www.corganisers.org.uk/news/massiveexpansion-community-organisers-programme.

Craig, G., Mayo, M., Popple, K., Shaw, M. and Taylor, M. (2011) The community development reader, Bristol: Policy Press.

DeFilippis, J., Fisher, R. and Shragge, E. (2010) Contesting community: The limits and potential of local organizing, New Brunswick, NJ: Rutgers University Press.

Delgado, G. (2009) 'Does ACORN's Work Contribute to Movement Building?', in $\mathrm{R}$. Fisher (ed) The people shall rule: ACORN, community organizing, and the struggle for economic justice, Nashville, TN: Vanderbilt University Press, pp 251-74.

Dodge, J., Hofmann-Pinilla, A., Beard, A. and Murphy, C. (2013) Beyond foundation funding: Revenue-generating strategies for sustainable social change, New York University, https://wagner.nyu.edu/ leadership/research/past-projects/sustainable\#.

Dorfman, A. and Fine, M. (2009) Seizing the moment: Frank advice for community organizers who want to raise more money, Washington, DC: National Committee for Responsive Philanthropy and Center for Community Change, www.ncrp.org/wp-content/uploads/2016/11/ seizingthemoment.pdf.

Dreier, P. (1996) 'Community empowerment strategies', Cityscape, 2(2): 121-59.

Edwards, M. (2010) Civil Society (2nd edn), Cambridge: Polity Press.

7

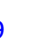

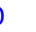


Edwards, M. (2013) "Beauty and the beast" Can money ever foster 1 social transformation?', Hivos Knowledge Programme, June, The 2 Hague: Humanist Institute for Cooperation with Developing 3 Countries, www.hivos.org/sites/default/files/m_edwards_beauty_ 4 and_the_beast.pdf. [[FYI this reference has been changed. The 5 one supplied conflated two other works by Edwards into a 6 single ref (one of which had a similar title), but this is the 7 one that has the quotation you used.]] 8

Ehrenberg, J. (2011) 'The history of civil society ideas', in M. Edwards 9 (ed), The Oxford handbook of civil society, Oxford: Oxford University 10 Press, pp 15-28.

Fabricant, M. and Fisher, R. (2002) Settlement houses under siege: The 12 struggle to sustain community organizations in New York City, New York: 13 Columbia University Press. 14

Fisher, R. (1994) Let the people decide: Neighborhood organizing in America, 15 Boston, MA: Twayne. 16

Fisher, R. and Dimberg, K. (2015) 'The community organisers 17 programme in England', Journal of Community Practice, 24(1): 94-108. 18

Fisher, R. and Shragge, E. (2017) 'Funding community organising: 19 Lessons from England and Quebec', Community Development Journal, 20 52(3): 454-69. 21

Fisher, R., Brooks, F. and Russell, D. (2007) " "Don't be a blockhead": 22 ACORN, direct action, and refund anticipation loans', Urban Affairs 23 Review, 42(4): 553-582. 24

INCITE! Women of Color Against Violence (eds) (2007) The revolution 25 will not be funded: Beyond the non-profit industrial complex, Cambridge, 26 MA: INCITE! and South End Press Collective. 27

Joseph, M. (2002) Against the romance of community, Minneapolis, MN: 28 University of Minnesota Press. 29

Kearney, S. and Olsen, J. (2009) A guide to root solutions: Listening matters 30 - engagement that works, London: Action to Regenerate Community 31 Trust.

Korstad, R.R. and Leloudis, J.L. (2010) To right these wrongs: The 33 North Carolina Fund and the battle to end poverty and inequality in 1960s 34 America, Chapel Hill, NC: University of North Carolina Press. 35

Larner, W. and Craig, D. (2005) 'After neoliberalism? Community 36 activism and local partnerships in Aotearoa New Zealand', Antipode, $\quad 37$ 37(3): 402-24. 38

Locality (2010) Tender to provide a national partner for the Community 39 Organisers Programme, formerly available at: http://locality.org.uk/ 40 projects/community-organisers/. 41 
Nicholls, A. (2011) The social enterprise investment fund (SEIF) evaluation: The landscape of social investment in the UK, Oxford: Third Sector Research Centre. [[Check this - I can't find this document you mention. And I can't find the quotation on p. 115 in other documents I tracked down with similar titles, by Nicholls or others.]]

O'Hara, M. (2014). Austerity bites: A journey to the sharp end of cuts in the UK, Bristol: Policy Press.

Piven, F.F and Cloward, R.A. (1978) Poor people's movements: Why they succeed, how they fail, New York: Vintage.

Rathke, W. (2015) 'Bristol wins first agreement for improved rental standards', Chief Organizer Blog, 15 March, http://chieforganizer. org/2015/03/15/bristol-wins-first-agreement-for-improved-rentalstandards/.

Salamon, L.M. (ed) (2002) The tools of government: A guide to the new governance, New York: Oxford University Press.

Scott, M. (2011) 'Reflections on the "Big Society"', Community Development Journal, 46(1): 132-37.

Smith, S.R. (2011) 'The nonprofit sector', in M. Edwards (ed) The Oxford handbook of civil society, Oxford: Oxford University Press, pp 29-41.

Staples, L. (2004) Roots to power: A manual for grassroots organizing, Westport, CT: Praeger.

Taylor, M. (2011) 'Community organising and the Big Society: Is Saul Alinsky turning in his grave?' Voluntary Sector Review, 2(2): 257-64.

Taylor, M. and Wilson, M. (2016) 'Community organising for social change: The scope for class politics', in M. Shaw and M. Mayo (eds), Class, Inequality and Community Development, Bristol: Policy Press, pp 219-34.

Third Sector (2011) 'Analysis: Why Alinsky's supporters lost out', Third Sector, 8 March, www.thirdsector.co.uk/analysis-why-Alinskysupporters-lost/infrastructure/article/1058293.

Trudeau, D. (2012) 'Constructing citizenship in the shadow state', Geoforum, 43(3): 442-52.

Waheed, S., Kim, M. and Davis, W. (2010) Sustaining organizing: A survey of organizations during the economic downturn, Washington, DC: Data Center and National Organizers Alliance, http://noacentral. org/files/public/docs/SOSReport\%202010.pdf. 
Walker, E. and McCarthy, J. (2012) 'Continuity and change in 1 community organizing', Social Policy, 42(2): 3-7. [[Check this. I 2 can't find this in the journal's archives, and it doesn't appear 3 in Walker's CV, but this does: Walker, Edward T. and John D. 4 McCarthy. 2012. Continuity and Change in Community Organizing: 5 A Report to Organizers. Los Angeles, CA: UCLA. Please confirm 6 the correct reference]] 7

Warren, M.R. (2001) Dry bones rattling: Community building to revitalize 8 American democracy, Princeton, NJ: Princeton University Press. 9

Wolch, J.R. (1990) The shadow state: Government and voluntary sector in 10 transition, New York: Foundation Center. 11 